\title{
Affetmenin Yordayıcısı Olarak Duygusal Zekâ
}

\author{
Trait Emotional Intelligence as Predictor of Forgiveness
}

Esra ASICI

\section{Öz}

$\mathrm{Bu}$ çalışmada duygusal zekâ özelliğinin üniversite öğrencilerinin affetme düzeyi üzerindeki yordayıcı rolü incelenmiştir. Araştırmanın katılımcılarını Dokuz Eylül Üniversitesi’nin çeşitli fakültelerinde okumakta olan 201'i kadın, 107'si erkek olmak üzere toplam 308 üniversite öğrencisi oluşturmuştur. Veriler Heartland Affetme Ölçeği, Duygusal Zeka Özelliği Ölçeği Kisa Formu ve araştırmacı tarafından hazırlanan kişisel bilgi formu aracilığıyla online olarak toplanmıştır. Verilerin analizinde pearson momentler çarpımı korelasyon katsayısı ve çoklu doğrusal regresyon analizi teknikleri kullanılmıştır. Bulgulara göre, üniversite öğrencilerinin affetme düzeyi ile duygusal zekâ özelliği arasında istatistiksel olarak anlamlı düzeyde ve pozitif yönde ilişki vardır. Duygusal zekâ özelliğinin iyi oluş, öz kontrol, duygusallık ve sosyallik alt boyutları birlikte üniversite öğrencilerinin affetme düzeyindeki değişimin \%27'sini açıklamaktadır. İyi oluş ve öz kontrol üniversite öğrencilerinin affetme düzeyini istatistiksel anlamlı olarak yordarken; duygusallık ve sosyallik üniversite öğrencilerinin affetme düzeyi üzerinde istatistiksel olarak anlamlı bir etkiye sahip değildir. Elde edilen bulgular ilgili literatür ışığında tartışılarak gelecek araştırmalar için öneriler sunulmuştur.

Anahtar Kelimeler: Affetme, Duygusal Zeka Özelliği, Üniversite Öğrencileri

\section{Abstract}

In this study, the predictive role of trait emotional intelligence on forgiveness level of university students was examined. Participants consisted of 201 female and 107 male, totally 308 university students who studied at different faculties of Dokuz Eylul University. The data was collected with Heartland Forgiveness Scale, Trait Emotional Intelligence Questionnaire-Short Form and personal information form prepared by the researcher. In data analysis Pearson product moment correlation coefficient and multiple linear regression analysis techniques were used. According to findings, there were statistically significant and positive relationships between forgiveness levels

* $\quad$ Arş. Gör., Dokuz Eylül Üniversitesi, Buca Eğitim Fakültesi, Eğitim Bilimleri Bölümü, esra.asici@deu.edu.tr 
and trait emotional intelligence of university students. Well-being, self-control, emotionality and sociability sub-dimensions of trait emotional intelligence accounted for $27 \%$ of change in forgiveness. While well-being and self-control significantly predicted forgiveness level of university students, emotionality and sociability didn't have a statistically significant effect on forgiveness levels of university students. Obtained findings were discussed in the light of related literature and suggestions were offered.

Keywords: Forgiveness, Trait Emotional Intelligence, University Students

\section{Giriş}

Din ve felsefe alanlarında uzun yıllar ilgi görmesine rağmen; psikoloji alanında bilimsel bir araştırma konusu olması 80'li yıllara dayanan (McCullough, Pargament ve Thoresen, 2000) affetme kavramının nasıl tanımlanması gerektiği konusunda farklı görüşler bulunmaktadır. Dini bakış açısından; Tanrısal affetmeye dayalı olarak açıklanan (Rye ve ark., 2000) kavram, felsefi bakış açısından kişilerarası bağlamda ele alınmaktadır (North, 1987). Psikolojik bir kavram olarak affetmeyi; bireyin kendisini derin şekilde inciten kişiye karşı mücadele etmekten vazgeçerek, onu koşulsuz olarak kabul ettiği (Enright, Gassin ve Wu, 1992), içsel (McCullough, Pargament ve Thoresen, 2000) ve kişilerarası (Hill, 2001) bir süreç olarak tanımlamak mümkündür. Affetmenin kusurlu görülen kişiye yardımseverlikle yaklaşıp, ona karşı duyulan öfkeden vazgeçme yönündeki yatkınlığı gösteren bir kişilik özelliği (Roberts, 1995); stresle başa çıkmaya yönelik duygu odaklı bir strateji (Worthington ve Scherer, 2004) ve başarılı bir ilişkiyi sürdürebilmek için potansiyel olarak her bireyin sahip olabileceği bir kişisel yeterlilik (Entezar, Othman, Kosnin ve Panah, 2011; Hodgson ve Wertheim, 2007) olduğu yönünde görüşler de bulunmaktadır.

Affetmenin çok boyutlu bir yapı olduğu ve bireyin kendisini, diğer insanları ya da kontrol edilemeyen durumları affetmesinin mümkün olduğu (Thompson, Snyder, Hoffman, Michael, Rasmussen ve Billings, 2005) vurgulanmakla birlikte; affetmeyi açıklamaya yönelik kuramsal modellerin daha çok kişilerarası ilişkilerde affetme üzerinde durduğu görülmektedir (Enright ve The Human Development Study Group, 1996; Hargrave ve Sells, 1997; Goldman ve Wade, 2012; McCullough ve ark., 1998; Worthington, 1998; Wade ve Meyer, 2009). Bu modellere göre, başkasını affetme süreci; duyguları fark etme ve tanıma, olumsuz duygulardan vazgeçme, suçluyla empati kurma, suçluya karşı olumlu duygular geliştirme, incitici olaya ilişkin bilişsel tekrarları fark etme, incitici duruma ilişkin bakış açısını değiştirme, suçlunun sınırlılıklarını, çabalarını ve niyetini dikkate alma, yıkıcı davranışları fark etme, affetmeyi bir seçenek olarak düşünme, yeniden güvenilir bir ilişki kurmak için suçluyla etkileşime geçme ve affettiğini açık davranışlarla gösterme gibi öğeleri içermektedir.

Allemand, Amberg, Zimprich ve Fincham' a (2007) göre; affetme, yakın ilişkilerde olumsuz duygular ortaya çıkaran ve ilişkiyi bozma gücüne sahip, zarar verici eylemler meydana geldiğinde, zarar verici eylemle başa çıkmaya yardımcı olmakta, kısa ve uzun süreli olumlu sonuçlar ortaya çıkarmaktadır. Bireyin affetme düzeyi arttıkça stres düzeyi azalırken (Asıcı 
ve Uygur, 2017); psikolojik ve fizyolojik iyi oluş düzeyi artmaktadır (Avery, 2008; Bono, McCullough ve Root, 2007; Koç, İskender, Çolak ve Düşünceli, 2016; Lawler Row ve Piferi, 2006). Bu bilgilerden yola çıkılarak, temel gelişimsel görevin yakın kişilerarası ilişkiler kurarak bunları sürdürebilmek olduğu beliren yetişkinlik dönemindeki (Santrock, 2011) üniversite öğrencilerinin affetme düzeylerinin yüksek olmasının onların kişilerarası ilişkilerini sağlıklı bir şekilde yürütmelerine yardımcı olarak psikolojik sağlıklarını olumlu yönde etkileyeceği ve gençler için daha verimli, mutlu ve sağlıklı bir yaşam sürdürmenin bir aracı olabileceği düşünülmektedir. Bu nedenle üniversite öğrencilerinin affetme düzeyi ile ilişkili değişkenleri belirlemeye yönelik çalışmalar yapmanın önemli olduğuna inanılmaktadır. Yapılan araştırmalar affetmenin empati (Macaskill, Maltby ve Day, 2002), ruminasyon (Barber, Maltby ve Macaskill, 2005), benlik saygısı (Eaton, Struthers, Shomrony ve Santelli, 2007), kişilik özellikleri (Arslan, Mert ve Yildız, 2016; Brose, Rye, Lutz Zois ve Ross, 2005; Ross, Kendall, Mattersi Rye ve Wrobel, 2004), öz-anlayış (Sarıçam ve Biçer, 2015), öz kontrol (Burnette, Davidson, Finkel, Tongeren, Hui ve Hoyle, 2014) ve belirsizliğe tahammülsüzlük (Koç, İskender, Çolak ve Düşünceli, 2016) gibi değişkenlerle ilişkili olduğunu göstermektedir. Bu araştırma kapsamında ise üniversite öğrencilerinin affetme düzeyi ile ilişkili olduğu düşünülen bir değişken olarak duygusal zekâ özelliği kavramı ele alınmaktadır.

Sosyal zekânın bir türü olarak görülen duygusal zekâ, "kişinin kendisinin ve başkalarının duyguların izleme, duygular arasında ayrım yapma ve bu bilgiyi eylem ve düşüncelerine rehberlik edecek şekilde kullanma yeteneğì" olarak tanımlanmaktadır (Salovey ve Mayer, 1990:189). Petrides ve Furnham (2000a, 2000b) duygusal zekânın "bilgi işlem süreci” ve “özellik” olmak üzere iki farklı yapı olarak ele alınması gerektiğini belirtmektedir. Bilgi işlem süreci olarak duygusal zekâ, duyguları tanımlama, açıklama ve sınıflandırma gibi bilişsel-duygusal yetenekleri ifade ederken; kişilik özelliği olarak duygusal zekâ, bireyin algıladığı yeteneklerini kapsamakta ve davranışsal yatkınlığı anlatmaktadır. Duygusal zekâ özelliği iyi oluş, öz-kontrol, duygusallık ve sosyallik boyutlarından oluşmakta (Petrides ve Furnham, 2003) ve uyumluluk, atılganlık, duyguların değerlendirilmesi, duyguların dışa vurumu, duyguların yönetimi, duyguların düzenlenmesi, düşük dürtüsellik, iletişim becerileri, benlik saygısı, öz-motivasyon, stres yönetimi, sosyal yeterlilik, empati, mutluluk ve iyimserliği içermektedir (Petrides ve Furnham, 2001).

Duygusal zeka; duygusal öz-farkındalık, duygusal dışavurum ve duygu yönetimi yönleriyle olumsuz yaşam olaylarının etkilerine karşı bir tampon görevi görmektedir (Armstrong, Galligan ve Critchley, 2011). Yüksek duygusal zekâya sahip olan insanlar duygularını doğru olarak algılayıp değerlendirebildikleri, duygularını ne zaman ve nasıl açıklamaları gerektiğini bildikleri ve duygu durumlarını etkili olarak düzenleyebildikleri (Salovey, Bedell, Detweiler ve Mayer, 1999) için stresli yaşam olayları karşısındaki davranışları daha uyum sağlayıcı olmaktadır (Armstrong, Galligan ve Critchley, 2011). Yüksek duygusal zekâ özelliğine sahip kişilerin hatalarla aşırı ilgilenmeyi içeren mükemmeliyetçilik (Saracaloğlu, Saygı, Yenice ve Altın, 2016) ve olumsuz olaylara ilişkin ruminasyon yapma eğilimlerinin düşük; uyum sağlayıcı stratejileri kullanma eğilimlerinin ise yüksek olması olası görülmektedir (Petrides, Pita ve Kokkinaki, 2007). Ayrıca araştırmalar duygusal zekâ düzeyi arttıkça; sosyal beceri 
(Dicle, 2006), stresle başa çıkma (Deniz ve Yılmaz, 2006) ve problem çözme becerilerinin de arttığını (Karabulutlu, Yılmaz ve Yurttaş, 2011); bütünleştirme ve uzlaşmaya dayalı çatışma çözme (Aslan, 2008) ve problemi çözmeye yönelik stresle başa çıkma yöntemlerinin daha çok kullanıldığını (Deniz ve Yılmaz, 2006) ve saldırgan davranışların da azaldığını (Kaynak, 2013) göstermektedir.

Duygularını doğru olarak tanımlayabilen, duygularının kendisini nasıl etkilediğini bilerek onları yönetebilen kişiler, sıkıntılı süreçlerde bile olumlu duygular geliştirebilmektedir. Düşünce ve davranışlara rehberlik eden bu olumlu duygular, bireyin güç durumlarla başa çıkmasında ve stres verici yaşantıların etkilerinden kurtulmasında yardımcı olmaktadır (Özer ve Deniz; 2014). Duygularına dikkat eden, duyguları hakkında açık olan ve duygularını düzenleyebilen kişilerin affetmeye daha yatkın olduğu (Hodgson ve Wertheim, 2007) ve affetme düzeyi yüksek olan kişilerin, öfkelerini ve affetmeyi engelleyen duygularını kontrol etmelerini sağlayan gelişmiş duygu yönetimi becerilerine sahip oldukları ileri sürülmektedir (Roberts, 1995). Buna göre, duyguların değerlendirilmesini, ifade edilmesini, düzenlenmesini ve problem çözme sürecinde kullanılmasını içeren duygusal zekânın (Salovey ve Mayer, 1990) affetme üzerinde belirleyici bir rolü olduğu ve duygusal zekâ düzeyinin yüksek olmasının öfke, incinme ya da hayal kırıklığı gibi olumsuz duygular üreten yaşantılara karşı daha olumlu yaklaşarak, affedici tutumlar sergilemeyi teşvik edebileceği düşünülmektedir. Nitekim affetmeye ilişkin literatür incelendiğinde; affetmenin uyumsuz duyguları başarıyla anlama ve çözümleme yeteneğiyle ilişkili olduğu (Worthington ve Wade, 1999), affetme modellerinin bireyin yaşadığı duyguların farkında olmasını, olumsuz duygularıyla başa çıkabilmesini ve empati kurabilmeyi içerdiği (Enright ve The Human Develepment Group, 1996; Worthington, 1998) ve affetmenin uzlaşmaya giden yolda atılan bir adım olarak ele alındığı (North, 1987; Worthington ve Wade, 1999) görülmektedir. Bu yönleriyle affetme ve duygusal zekâ özelliğinin birbirleriyle yakından ilişkili olduğu söylenebilir.

Affetme düzeyi yüksek olan bireyler, duygularını doğru bir şekilde tanımlayarak, yönetebilecek, suçlu kişi ile empati kurarak ona karşı daha hoşgörülü yaklaşabilecektir. Duyguları tanıma, yönetebilme ve empati ise duygusal zekanın farklı yönlerini oluşturmaktadır. Bu nedenle, yüksek duygusal zekânın affetme üzerinde olumlu bir etkiye sahip olacağı düşünülmektedir. Yapılan literatür taraması sonucunda affetme ve duygusal zeka arasındaki ilişkileri ele alan çalışmaların az sayıda olduğu ve çalışmalardan elde edilen bulguların birbiriyle çeliştiği görülmektedir. Örneğin, Van Dyke ve Elias (2008) tarafından gerçekleştirilen çalışmada olumsuz affetme görüşüne sahip beşinci sınıf öğrencilerinin duygusal zeka düzeylerinin düşük olduğu görülürken; yetişkinler ve evli bireylerle gerçekleştirilen bir grup çalışmada ise affetme ile duygusal zeka arasında ilişki olmadığı görülmektedir (Entezar ve ark.,2011; Mugrage, 2014; Panah, Shariff ve Entezar, 2011). Bu bulgulara göre, iki değişken arasındaki ilişkinin varlığ 1 ve ilişkinin yönü konusunda daha net bir sonuca ulaşmak için farklı örneklem gruplarında yeni araştırmaların yapılmasına ihtiyaç duyulmaktadır. Bu araştırmada da üniversite öğrencilerinin affetme düzeyi ile duygusal zekâ özelliği arasındaki ilişkileri ve duygusal zekâ özelliğinin öğrencilerin affetme düzeyi üzerindeki yordayıcı etkisini belirlemek amaçlanmaktadır. 


\section{Yöntem}

\section{Araştırmanın Modeli}

$\mathrm{Bu}$ çalışma, yordayıcı korelasyonel araştırma modeline dayanmaktadır. Yordayıcı korelasyonel araştırmalar bir ya da daha çok bağımsız değişkene dayalı olarak bağımlı değişkende meydana gelen değişimleri açıklamaya yöneliktir (Büyüköztürk, Kılıç Çakmak, Akgün, Karadeniz ve Demire, 2012).

\section{Evren ve Örneklem}

Araştırmanın evrenini 2015-2016 eğitim öğretim yılında Dokuz Eylül Üniversitesi’nde okumakta olan üniversite öğrencileri oluşturmaktadır. Araştırmanın örneklemi, ölçek formlarının çevrimiçi ortamda paylaşılması yoluyla, ulaşılabilir örnekleme yöntemine göre belirlenen, araştırmaya katılmaya gönüllü olan, \%65.3’ü (n: 201) kadın, \%34.7’si (n: 107) erkek olmak üzere toplam 308 öğrenciden oluşmaktadır. Katılımcıların yaş ortalaması 21.31'dir (ranj:17-28). Katılımcıların \%12.7'si (n:39) ekonomik durumunu düşük, \%84.1’i (n: 84.1) orta, \%3.2'si (n:10) ise yüksek olarak algıladığını belirtmiştir.

\section{Veri Toplama Araçları}

Araştırmada ölçme aracı olarak Heartland Affetme Ölçeği ve Duygusal Zekâ Özelliği Ölçeği Kısa Formu kullanılmıştır. Öğrencilere ait kişisel bilgiler araştırmacı tarafından oluşturulan Kişisel Bilgi Formu aracılığıyla toplanmıştır.

Heartland Affetme Ölçeği (HAÖ): Thompson ve arkadaşları (2005) tarafından geliştirilen HAÖ bireylerin affetme eğilimlerini ölçmeyi amaçlamaktadır. 18 maddeden oluşan 7’li Likert tipindeki ölçekten alınan yüksek puanlar bireyin affetme eğiliminin yüksek olduğunu göstermektedir. Ölçeğin kendini, başkalarını ve durumu affetmek olmak üzere üç alt boyutu bulunmaktadır. Ayrıca ölçek genel affetme eğilimini belirlemeye yönelik olarak toplam bir puan da vermektedir. $\mathrm{Bu}$ araştırma kapsamında ölçekten alınan toplam puanlar kullanılmıştır. Ölçeğin Türk kültürü için çeviri ve uyarlama çalışması Bugay ve Demir (2010) tarafından yapılmıştır. Ölçeğin Türkçe formunun Cronbach a iç tutarlılık katsayısı kendini affetme için .64, başkalarını affetme için .79, durumu affetme için .76 ve ölçeğin tümü için .81 olarak hesaplanmıştır.

Duygusal Zekâ Özelliği Ölçeği Kısa Formu (DZÖÖ-KF): Petrides ve Furnham (2000a, 2001) tarafından geliştirilen DZÖÖ-KF, duygusal zekâyı kişisel karakter özelliği olarak kavramsallaştırmakta ve bireyin duygusal yeterlikleriyle ilgili kendini algılama düzeyini ölçmeyi amaçlamaktadır. 30 maddeden oluşan 7’li likert tipindeki ölçeğin iyi oluş, öz kontrol, duygusallık ve sosyallik olmak üzere dört alt ölçeği bulunmaktadır. Ölçekten alınan puanların yükselmesi ilgili özelliğin yüksek olduğu anlamına gelmektedir. Ölçeğin Türkçeye çeviri ve uyarlama çalışmaları Deniz, Özer ve Işı (2013) tarafından gerçekleştirilmiştir. Uyarlama çalışması kapsamında gerçekleştirilen açıklayıcı faktör analizi sonucunda toplam varyansın \%53'ünü açıklayan dört faktörlü bir yapının ortaya çıktığı görülmüştür. Ortaya çıkan dört faktörlü yapının örneklem verisine iyi uyum gösterip göstermediğini belirlemek amacıyla yapılan doğrulayıcı faktör analizi 
sonucunda, ölçeğin iyi uyum gösterdiği saptanmıştır $\left(X^{2} / \mathrm{sd}=2.46, \mathrm{GFI}=.95, \mathrm{AGFI}=.92, \mathrm{CFI}=.91\right.$, RMSEA=.056 ve SRMR=.060). Ölçeğin Cronbach $\alpha$ iç tutarlık katsayısı iyi oluş için .72, öz kontrol için .70, duygusallık için .66, sosyallik için .70 ve ölçek toplam puanı için .81 olarak bulunmuştur.

\section{Veri toplama süreci}

Araştırmanın verilerini toplamak için ölçek formları Google Formlar sayfası üzerinde çevrimiçi bir form haline getirilmiştir. Hazırlanan çevrimiçi formda öncelikle araştırmanın Dokuz Eylül Üniversitesi’nde okumakta olan öğrencilere yönelik olduğu, araştırmaya katılımın gönüllülük esasına dayandığı belirtilmiş, ardından da araştırmanın amacı ve veri toplama araçlarının nasıl doldurulması gerektiği açıklanmıştır. Hazırlanan çevrimiçi form araştırmacı tarafından sosyal iletişim ağı Facebook üzerindeki Dokuz Eylül Üniversitesi başlıklı grup sayfalarında (Örnek sayfa adları: DEU Buca Eğitim Fakültesi, DEU istatistik öğrenci topluluğu, DEU 2014 girişliler, DEU PDR öğrenci topluluğu, DEU Mühendislik fakültesi, DEU Güzel sanatlar, DEU Tip Fakültesi gibi.), iki hafta boyunca paylaşılmıştır. Ölçek linkinin aynı grup sayfasında en fazla iki kez paylaşılmasına dikkat edilmiş ve ikinci paylaşımlarda formu daha önce dolduran öğrencilerin ikinci kez doldurmaması istenmiştir. İki haftalık sürenin sonunda toplam 308 üniversite öğrencisine ulaşılmıştır.

\section{Verilerin analizi}

Veri analizi SPSS 15.00 istatistik paket programı aracılığıyla gerçekleştirilmiştir. Analizlerde frekans dağılımı, aritmetik ortalama, pearson korelasyonu ve çoklu regresyon analizi teknikleri kullanılmıştır. Çoklu doğrusal regresyon analizi bir değişken üzerinde etkisi olan bir dizi değişkenin etkilerinin derecelerini ve bu değişkenlerdeki değişimi açıklamadaki önceliklerini belirlemek amacıyla gerçekleştirilmektedir (Can, 2014). Çoklu doğrusal regresyon analizi yapabilmek için karşılanması gereken bazı varsayımlar bulunmaktadır. Bunlar; (a) hata terimlerinin dağılımı normaldir, (b) hata terimleri dağılımının aritmetik ortalaması sıfırdır, (c) hata terimleri arasında otokorelasyon yoktur, (d) hata terimlerinin her birinin dağılımının varyansları sabittir ve (e) çoklu doğrusal bağlantı problemi yoktur şeklinde sıralanabilir (Güriş ve Astar, 2014).

Regresyon analizine başlanmadan önce veri setinin gerekli varsayımları karşılayıp karşılamadığ terimleri dağılımının normal (KS=.05, p>.05) ve aritmetik ortalamasının sıfır olduğu saptanmıştır. Hata terimleri arasında otokorelasyon olup olmadığını test etmek amacıyla yapılan Durbin Watson testi sonucunda elde edilen değerin 1.5-2.5 arasında olması gerektiği belirtilmektedir (Küçüksille, 2014). Bu çalışmada ise Durbin Watson değeri 1.97 olarak hesaplanmıştır. Yapılan homojenlik testi sonucunda hata terimleri dağılımının varyanslarının sabit olduğu bulunmuştur $(\mathrm{F}=.00, \mathrm{p}=1.00)$. Bağımsız değişkenler arasındaki korelasyonun .90 'dan büyük olması, VIF değerinin 10'dan büyük ve tolerans değerinin de .10'dan küçük olması durumunda çoklu bağlantı probleminin varlığından bahsedilmektedir (Çokluk, Şekercioğlu ve Büyüköztürk, 2012). Araştırmada bağımsız değişkenler arasındaki ilişkiler incelendiğinde korelasyon katsayılarının .23 ile .40 arasında, VIF değerlerinin 1.1 ile 1.3 arasında ve tolerans değerlerinin de .75 ile 
.85 arasında olduğu görülmüştür. Buna göre, bağımsız değişkenler arasında çoklu bağlantı probleminin olmadığı söylenebilir. Yapılan incelemeler sonucunda veri setinin çoklu doğrusal regresyon analizi yapabilmek için gerekli koşulları sağladığı sonucuna ulaşılmıştır.

\section{Bulgular ve Yorumlar}

Araştırmaya katılan üniversite öğrencilerinin ölçeklerden aldıkları puanlara ilişkin aritmetik ortalama, standart sapma, minimum ve maksimum değerler Tablo 1'de verilmektedir.

Tablo I

HAÖ ve DZÖÖ-KF'ye Illişkin Aritmetik Ortalama, Standart Sapma ve Minimum-Maksimum Değerler

\begin{tabular}{lllll}
\hline & $\bar{X}$ & Std. Sap. & Min. & Max. \\
\hline Affetme & 77.97 & 16.26 & 27 & 125 \\
İyi oluş & 18.54 & 4.97 & 4 & 28 \\
Öz kontrol & 17.27 & 4.97 & 4 & 28 \\
Duygusallık & 19.07 & 3.86 & 5 & 28 \\
Sosyallik & 19.78 & 4.70 & 4 & 28 \\
Duygusal zekâ özelliği & 92.83 & 16.59 & 45 & 134 \\
\hline
\end{tabular}

Tablo 1'de görüldüğü gibi, araştırmaya katılan öğrencilerin affetme ölçeğinden aldıkları toplam puan ortalamalarının ( $\bar{X}=77.97)$ olduğu saptanmıştır. DZÖÖ-KF'dan alınan puan ortalamaları incelendiğinde iyi oluş ( $\bar{X}=18.54)$, öz kontrol ( $\bar{X}=17.27)$, duygusallık ( $\bar{X}=19.07)$, sosyallik ( $\bar{X}=19.78)$ ve duygusal zekâ özelliği toplam ( $\bar{X}=92.83$ ) olarak bulunmuştur.

Üniversite öğrencilerinin affetme düzeyi ile duygusal zeka özelliği arasındaki ilişkiyi gösteren pearson momentler çarpımı korelasyon katsayısı analiz sonuçları Tablo 2'de verilmektedir.

\section{Tablo 2}

Affetme ile Duygusal Zekâ Özelliği Arasındaki Illişkilere Illişkin Pearson Korelesyon Analizi Sonuçları

\begin{tabular}{lll}
\hline & & Affetme \\
\cline { 2 - 3 } Duygusal zeka özelliği & İyi oluş & $.45^{*}$ \\
& Öz kontrol & $.38^{*}$ \\
& Duygusallık & $.24^{*}$ \\
& Sosyallik & $.27^{*}$ \\
\hline
\end{tabular}

${ }^{*} \mathrm{p}<.05$ 
Tablo 2'de görüldüğü gibi, affetme ölçeğinden alınan toplam puanlar ile duygusal zekâ özelliğinin iyi oluş $(\mathrm{r}=.45, \mathrm{p}>.01)$, öz kontrol $(\mathrm{r}=.38, \mathrm{p}<.01)$, duygusallık $(\mathrm{r}=.24, \mathrm{p}<.01)$ ve sosyallik $(\mathrm{r}=.27, \mathrm{p}<.01)$ boyutları arasında istatistiksel olarak anlamlı düzeyde pozitif yönde ilişkiler vardır.

Duygusal zeka özelliğinin üniversite öğrencilerinin affetme düzeyi üzerindeki yordayıcı etkisini belirlemek amacıyla gerçekleştirilen çoklu doğrusal regresyon analizi sonuçları Tablo 3’te verilmektedir.

Tablo3

Duygusal Zekâ Özelliğinin Affetmeyi Yordayıcı Etkisine Yönelik Çoklu Doğrusal Regresyon Analizi Sonuçları

\begin{tabular}{llllllll}
\hline & $\mathrm{B}$ & Std. Hata & $\beta$ & $t$ & $p$ & İkili r & Kismi r \\
\hline Sabit & 35.22 & 4.95 & & 7.12 & .00 & & \\
İyi oluş & 1.22 & 0.20 & 0.35 & 6.16 & .00 & .45 & .33 \\
Öz kontrol & 0.71 & 0.18 & 0.22 & 3.86 & .00 & .38 & .22 \\
Duygusallık & 0.35 & 0.23 & 0.08 & 1.57 & 0.12 & .24 & .09 \\
Sosyallik & 0.06 & 0.20 & 0.02 & 0.30 & 0.77 & .27 & .02 \\
\hline $\mathrm{R}=.52 \mathrm{R}^{2}=.27$ & & & & & & & \\
$\mathrm{~F}_{(4-303)}=27.36 \mathrm{p}=.00$ & & & & & & & \\
\hline
\end{tabular}

Tablo 3’te görüldügü gibi, yapılan çoklu doğrusal regresyon analizi sonucuna göre, duygusal zekâ özelliğinin boyutları olan iyi oluş, öz kontrol, duygusallık ve sosyallik birlikte üniversite öğrencilerinin affetme düzeylerini istatistiksel olarak anlamlı düzeyde yordamaktadır $(\mathrm{R}=.52$, $\left.\mathrm{R}^{2}=.27 ; \mathrm{F}_{(4-303)}=27.36, \mathrm{p}<.01\right)$. Söz konusu dört boyut birlikte, üniversite öğrencilerinin affetme düzeyine ilişkin varyansın \%27’sini açıklamaktadır. Standartlaştırılmış regresyon katsayılarına göre, yordayıcı değişkenlerin affetme üzerindeki göreli önem sırası iyi oluş ( $\beta=0.35)$, öz kontrol $(\beta=0.22)$, duygusallık $(\beta=0.08)$ ve sosyallik $(\beta=.0 .02)$ şeklindedir. Regresyon katsayılarının anlamlılığına ilişkin $t$ testi sonuçları incelendiğinde, sadece iyi oluş $(t=6.16, \mathrm{p}<.05)$ ve öz kontrolün $(t=3.86, \mathrm{p}<.05)$ affetmenin anlamlı yordayıcıları olduğu görülmektedir. Duygusallık $(t=1.57, \mathrm{p}>.05)$ ve sosyallik $(t=0.30, \mathrm{p}>.05)$ boyutlarının ise modele katkıları istatistiksel olarak anlamlı düzeyde değildir. İyi oluş puanlarında meydana gelen 1 birimlik artış, affetme düzeyinde 1.22 birimlik bir artışa, öz kontrolde meydana gelen 1 birimlik artış da affetme düzeyinde 0.71 birimlik bir artışa neden olmaktadır.

\section{Tartışma}

Duygusal zekâ özelliğinin affetmenin anlamlı bir yordayıcısı olup olmadığını incelemek amacıyla gerçekleştirilen bu araştırmada, öncelikle affetme ile duygusal zekâ özelliği arasındaki ilişkiler incelenmiş ve üniversite öğrencilerinin affetme düzeyi ile duygusal zekâ özelliğinin iyi oluş ve öz kontrol boyutları arasında orta; duygusallık ve sosyallik boyutları arasında da düşük düzeyde olumlu yönde ilişkilerin var olduğu saptanmıştır. Buna göre, üniversite öğrencilerinin 
iyi oluş, öz-kontrol, duygusallık ve sosyallik düzeyi arttıkça affetme düzeyi de artmaktadır. Araştırmanın bir diğer bulgusuna göre; iyi oluş, öz kontrol, duygusallık ve sosyallik birlikte üniversite öğrencilerinin affetme düzeylerindeki değişimin \%27’sini açıklamaktadır. Regresyon katsayılarının anlamlılığına ilişkin $t$ testi sonuçları incelendiğinde; iyi oluş ve öz kontrolün affetme düzeyinin istatistiksel olarak anlamlı yordayıcıları olduğu görülmektedir. Duygusallık ve sosyallik ise affetmeyi yordamada önemli bir etkiye sahip değildir.

Duygusal zekâ özelliğinin dört boyutunun (iyi oluş, öz kontrol, duygusallık ve sosyallik) bir arada affetme düzeyindeki değişimi anlamlı olarak yordadığı bulgusu giriş bölümünde ileri sürülen, duygusal zekâ özelliğinin affetme üzerinde olumlu bir etkisi olduğu görüşünü doğrulamaktadır. Buna göre, affetmeyi açıklamaya yönelik kuramsal modellerde ele alındığı gibi, affetme sürecinde duyguların üzerinde durulması gereken bir konu olduğu (Enright ve The Human Development Study Group, 1996; Hargrave ve Sells, 1997; Goldman ve Wade, 2012; McCullough ve ark., 1998; Worthington, 1998; Wade ve Meyer, 2009) ve duygusal zekâyı oluşturan duyguları doğru olarak algılayabilme, duyguları ne zaman ve nasıl açıklamak gerektiğini bilme ve duyguları yönetebilmenin affetmenin altında yatan temel elementlerden olduğu düşünülebilir.

Elde edilen sonuçlar; gelişmiş sosyal (Dicle, 2006) ve problem çözme becerilerine sahip olan (Karabulutlu, Yllmaz ve Yurttaş, 2011), stresle etkili olarak başa çıkabilen (Deniz ve Yılmaz, 2006), yaşam olayları karşısında daha uyum sağlayıcı davranışlar gösterebilen (Armstrong, Galligan ve Critchley, 2011; Petrides, Pita ve Kokkinaki, 2007) ve bütünleştirme ve uzlaşmaya yönelik çatışma çözme yöntemlerini kullanmaya eğilimli olan (Aslan, 2008) yüksek duygusal zekâya sahip kişilerin affetmeyi olumlu ve uyum sağlayıcı bir problem ya da çatışma çözme stratejisi olarak kabul ettiklerinin göstergesi olabilir. Ayrıca, ruminasyon yapma eğiliminin affetmeyi zorlaştırdığı (Barber, Maltby ve Macaskill, 2005; McCullough, Bellah, Kilpatrick ve Johnson, 2001) ve duygusal zekâ ile ruminasyon yapma eğilimi arasında olumsuz yönde ilişki olduğu (Petrides, Pita ve Kokkinaki, 2007) dikkate alındığında; yüksek duygusal zeka özelliğine sahip olan kişilerin, incitici olayları zihinlerinde sürekli tekrarlamaktan uzak olmalarının bir sonucu olarak; yaşadıkları incitici olaya ilişkin olumsuz duyguların şiddetini hafifletme konusunda daha başarılı oldukları ve böylece de daha affedici davranış sergileyebildikleri düşünülebilir.

Duygusal zekâ düzeyi düşük olan bireylerin olumsuz affetme görüşüne sahip olduklarını bulan Van Dyke ve Elias’ın (2008) bulgularıyla paralellik gösteren bu çalışmanın sonuçlarının; duygularına dikkat etmenin, duygular hakkında açık olmanın ve duygularını düzenleyebilmenin affetme ile ilişkili olduğu (Hodgson ve Wertheim, 2007) ve duyguları etkili bir şekilde yönetebilmenin affetmeyi kolaylaştırdığı (Roberts, 1995) görüşlerini desteklediği söylenebilir. Bununla birlikte sonuçlar, duygusal zeka özelliği ile affetme arasında ilişki olmadığını gösteren araştırmaların bulgularıyla uyuşmamaktadır (Entezar ve ark.,2011; Panah, Shariff ve Entezar, 2011). Araştırmaların bulguları arasındaki farklılıklar, katılımcıların bireysel özellikleri, kültürel faktörler ve kullanılan ölçme araçlarının aynı olmamasından kaynaklanmış olabilir.

Regresyon modeline dâhil edilen her bir duygusal zekâ özelliği boyutuna ilişkin bulgular incelendiğinde; iyi oluşun üniversite öğrencilerinin affetme düzeyinin istatistiksel olarak 
anlamlı bir yordayıcısı olduğu görülmektedir. Üniversite öğrencilerinin iyi oluş düzeyindeki 1 birimlik değişim affetme düzeylerinde 1.22 birimlik bir artış ortaya çıkarmaktadır. Elde edilen sonuç Mugrage'nin (2014) iyi oluş ile affetme arasında küçük; ancak anlamlı bir ilişki olduğu bulgusuyla paralellik göstermektedir. Ayrıca literatürde affetme ile bireyin psikolojik ve fizyolojik iyi oluşu arasında anlamlı ilişkiler olduğunu gösteren pek çok çalışma da yer almaktadır (Avery, 2008; Bono, McCullough ve Root, 2007; Koç, İskender, Çolak ve Düşünceli, 2016; Lawler Row ve Piferi, 2006). İyi oluş düzeyi düşük olan bir insan yaşamdaki her türlü kötü ve incitici olayın kendi başına geldiği düşüncesiyle olaylara çok daha olumsuz bir bakış açısıyla yaklaşarak, ani ve olumsuz tepkiler gösterebilir. Aksine kişinin iyi oluş düzeyinin yüksek olması hayata daha olumlu bakmasına, daha yapıcı düşünmesine ve davranmasına yardımcı olarak affetme düzeyinin artmasına katkı sağlıyor olabilir.

Regresyon modelindeki anlamlı yordayıcılardan bir diğeri ise öz kontroldür. Bulgular üniversite öğrencilerinin öz kontrol düzeyindeki 1 birimlik artışın affetme düzeylerinde 0.71 birimlik bir artışa neden olduğunu göstermektedir. Bu sonuç, Burnette ve arkadaşlarının (2014) affetmenin öz-kontrol ile pozitif yönde ilişki olduğunu gösteren bulgusuyla paralellik göstermektedir. Öz kontrol bireyin değişme ve uyum sağlama kapasitesini ifade etmektedir. Yetersiz öz kontrol pek çok istenmeyen davranışla ilişkiliyken yüksek öz kontrol daha iyi ilişkiler ve kişilerarası beceriler anlamina gelmektedir. (Baumeister, Vohs ve Tice, 2007, Tangney, Baumeister ve Boone, 2004). Öz kontrol sahibi kişiler kendi tepkilerini değiştirebildikleri için olumsuz yaşam olayları karşısında ortaya çıkan düşünce ve duygularını değiştirerek, ani ve olumsuz tepkiler vermek yerine sakin kalarak, olaylara daha olumlu bakabilirler. Yaşanan olayla ilgili duygu ve düşüncelerin değişmesi de affedici davranışları ortaya çıkarabilir.

Duygusal zekâ özelliğinin duygusallık ve sosyallik boyutlarının affetmenin anlamlı bir yordayıcısı olmadığı saptanmıştır. DZÖÖ-KF’nun duygusallık ve sosyallik boyutlarına ait maddeler incelendiğinde, duygusallı̆̆ın duyguları ayırt etme, duyguları gösterme, duygular hakkında düşünme ve kişilerarası bağ oluşturmayı içerdiği; sosyalliğin ise insanlarla başa çıkma, haklarını savunma, başkalarının duygularını etkileme ve kendini savunamamaya odaklandığı görülmektedir. Bu sonuç, affetme ile duygusal zekâ özelliği arasındaki ilişkilerin duyguları anlama, ifade etme ve kişilerarası ilişkileri yürütme biçiminden daha çok duyguları düzenleyebilmeye, yönetebilmeye ve duygusal ve davranışsal tepkilerini değiştirme gücüne sahip olmaya dayandığının bir göstergesi olarak yorumlanabilir.

$\mathrm{Bu}$ araştırmada veriler çevrimiçi olarak toplanmıştır. İnternetin gençler için çekici bir ortam olması nedeniyle, çevrimiçi anket uygulamalarının gençler tarafından daha olumlu karşılanabileceği ileri sürülmekle birlikte, çevrimiçi veri toplama sürecinde örneklem yanlılığı, ölçeklerin yanlış kişiler tarafından doldurulması ve ölçeklerin aynı katılımcı tarafından birden fazla kez yanıtlanması önemli problem alanları olarak görülmektedir (Coulson, 2016). Bu nedenle araştırmanın verilerinin çevrimiçi olarak toplanmış olması, araştırmanın önemli bir sınırlılığı olarak değerlendirilmelidir. 
Araştırmadan elde edilen bulgulara dayalı olarak, yükseköğretimde psikolojik danışma ve rehberlik hizmeti sunan birimlerin, affetme düzeyi düşük olan üniversite öğrencilerine yönelik olarak duyguları tanıma, ifade etme ve yönetme becerilerini içeren psikoeğitim programları hazırlayarak uygulaması önerilebilir. Ayrıca öz-kontrol becerilerini geliştirmeye ve iyi oluşu arttırmaya yönelik deneysel çalışmaların da affetme düzeyinin artmasına katkı sağlayabileceği düşünülmektedir. Örneğin, üniversite öğrencilerinin psikolojik gereksinimlerini belirleyerek bunları gidermeye yönelik çalışmalar yapmak, iyi oluşlarının artmasına yardımcı olarak affetme düzeylerinin de artmasına katkı sağlayabilir. Araştırmada duygusal zekâ özelliğinin affetmenin \%27’sini açıkladığı saptanmıştır. Bundan sonraki araştırmalarda başka hangi faktörlerin affetme üzerinde etkili olduğu incelenebilir. Affetme ile duygusal zekâ özelliği arasındaki ilişkiye çeşitli gizil değişkenlerin aracılık etmesi olasıdır. Bundan sonraki araştırmalarda affetme ile duygusal zekâ özelliği arasındaki ilişkiye aracılık eden değişkenler belirlenmeye çalışılabilir. Ayrıca bu araştırma sınırlı bir katılımcı grubu ile gerçekleştirildiğinden, ilerideki çalışmalar farklı yaş gruplarından ve farklı koşullara sahip bireylerde affetme ile duygusal zekâ arasındaki ilişkinin varlığını test edebilir. 


\section{Kaynaklar}

Allemand, M., Amberg, I.,Zimprich, D.ve Fincham, F. D. (2007). The role of trait forgiveness and relationship satisfaction in episodic forgiveness. Journal of Social and Clinical Psychology, 26 (2), 199-217.

Armstrong, A. R., Galligan, R. F., ve Critchley, C. R. (2011). Emotional intelligence and psychological resilience to negative life events. Personality and Individual Differences, 51(3), 331-336.

Arslan, M., Mert, H. Ş. ve Yıldız, M. (2016). Narsistik kişilik ile affedicilik arasındaki ilişkinin incelenmesi. 2. Uluslararası Çin'den Adriyatike Sosyal Bilimler Kongresi Bildiri Özet Kitapçı̆̆ı (s. 147-153), 5-7 Mayıs 2016, Payas/ HATAY.

Asıc1, E. ve Uygur, S. (2017). Duygusal öz-yeterlik ve affetmenin algılanan stres düzeyini yordayıcı rolü. Uluslararası İnsan ve Toplum Bilimleri Araştırmaları Dergisi, 6 (3), 1353-1375.

Aslan, Ş. (2008). Duygusal zekâ, bireylerarası çatışmayı çözümleme yöntemleriyle ilişkili midir? schutte’nın duygusal zekâ ölçeğinin geçerlilik ve güvenilirlik çalışması. Süleyman Demirel Üniversitesi İktisadi ve İdari Bilimler Fakültesi Dergisi, 13(3), 179-200.

Avery, C. M. (2008). The relationship between self-forgiveness and health: mediating variables and implications for well-being. (Unpublished doctoral dissertation). University of Hartford, Institute of Professional Psychology.

Barber, L.,Maltby, J. ve Macaskill, A. (2005). Angry memories and thoughts of revenge: the relationship between forgiveness and anger rumination. Personality and Individual Differences, 39, 253-262.

Baumeister, R. F., Vohs, K. D. ve Tice, D. M. (2007). The strength model of self-control. Current Directions in Psychological Science, 16(6), 351-355.

Bono, G.,McCullough, M. E. ve Root, L. M. (2007). Forgiveness, feeling connected to others, and well-being: two longitudinal studies. Personality and Social Psychology Bulletin, 34, 182 - 195.

Brose, L. A.,Rye, M. S.,Lutz-Zois, C. ve Ross, S. R. (2005). Forgiveness and personality traits. Personality and Individual Differences, 39, 35-46.

Burnette, J.L., Davisson, E. K., Finkel, E. J., Tongeren D. R. V. , Hui, C. M ve Hoyle R. H. (2014). Self-control and forgiveness: a meta-analytic review. Social Psychological and Personality Science, 5(4), 443-450, doi: $10.1177 / 1948550613502991$.

Bugay, A. ve Demir, A. (2010). A Turkish version of heartland forgiveness scale. Procedia Social and Behavioral Sciences, 5, 1927-1931.

Büyüköztürk, Ş.,Kılıç Çakmak, E.,Akgün, Ö. E.,Karadeniz, Ş. ve Demirel, F. (2012). Bilimsel araștırma yöntemleri (7. Baskı). Ankara: Pegem Akademi.

Can, A. (2014). SPSS ile bilimsel araştırma sürecinde veri analizi (3. Baskı) Ankara: Pegem Akademi.

Coulson, N. (2016). Psikologlar için çevrimiçi araştırma yöntemleri. (Çev Edt. Derya Hasta). Ankara: Nobel Akademik Yayıncllık

Çokluk, Ö., Şekercioğlu, G., ve Büyüköztürk, Ş. (2012). Sosyal bilimler için çok değişkenli SPSS ve LISREL uygulamaları (2. Baskı). Ankara: Pegem Akademi.

Deniz, M.E., Özer, E. ve Işık, E. (2013). Duygusal zekâ özelliği ölçeği-kısa formu: Geçerlik ve güvenirlik çalışması. Eğitim ve Bilim, 38 (169), 407-419.

Deniz, M. E. ve Yılmaz, E. (2006). Üniversite öğrencilerinin duygusal zeka ve stresle başa çıkma stilleri arasındaki ilişkinin incelenmesi. Türk Psikolojik Danışma ve Rehberlik Dergisi, 3 (25), 17-26.

Dicle, A. N. (2006). Üniversite öğrencilerinin sosyal beceri düzeylerinin duygusal zeka düzeyleri ve bazı kişisel özelliklerine göre incelenmesi. (Yayımlanmamış yüksek lisans tezi). Ondokuz Mayıs Üniversitesi Sosyal Bilimler Enstitüsü, Samsun. 
Eaton, J.,Struthers, C. W.,Shomrony, A. ve Santelli, G. (2007). When apologies fail: The moderating effect of implicit and explicit self-esteem on apology and forgiveness. Self and Identity, 6 (2-3), 209-222.

Enright, R. D.,Gassin, E.A. ve Wu, C. (1992). Forgiveness: A developmental view. Journal of Moral Education, 21, 99-114.

Enright, R. D. ve The Human Development Study Group (1996). Counseling within the forgiveness triad: on forgiving, receiving forgiveness and self - forgiveness. Counseling and Values, 40, 107-126.

Entezar, R. K., Othman, N., Kosnin, A. B. M., ve Panah, A. G. (2011). Relation between emotional intelligence and forgiveness with marital satisfaction. International Journal of Fundamental Psychology and Social Sciences, 1, 21-25.

Goldman, D. B., ve Wade, N. G. (2012). Comparison of forgiveness and anger-reduction group treatments: a randomized controlled trial. Psychotherapy Research, 22(5), 604-620.

Güriş, S. ve Astar, M. (2014). Bilimsel araştırmalarda SPSS ile istatistik. İstanbul: Der Yayınlar

Hargrave, T. D. ve Sells, J. N. (1997). The development of a forgiveness scale. Journal of Marital and Family Therapy, 23 (1), 41-62.

Hill, E. W. (2001). Understanding forgiveness as discovery: Implications for marital and family therapy. Contemporary Family Therapy, 23(4), 363 - 384.

Hodgson, L. K., ve Wertheim, E. H. (2007). Does good emotion management aid forgiving? Multiple dimensions of empathy, emotion management and forgiveness of self and others. Journal of Social and Personal Relationships, 24(6), 931-949.

Karabulutlu, E. Y., Yılmaz, S., ve Yurttaş, A. (2011). Öğrencilerin duygusal zekâ düzeyleri ile problem çözme becerileri arasındaki ilişki. Psikiyatri Hemşireliği Dergisi, 2(2), 75-79.

Kaynak, A. (2013). Eğitim fakültesi öğrencilerinin duygusal zeka düzeyleri ile saldırganlık düzeyleri arasındaki ilişkinin bazı değișkenler açısından incelenmesi. (Yayımlanmamıș yüksek lisans tezi). Gaziantep Üniversitesi Eğitim Bilimleri Enstitüsü, Gaziantep.

Koç, M., İskender, M., Çolak, T. S. ve Düşünceli, B. ( 2016). Investigation of the effect of intolerance of uncertainty and the effect of anger control on the relationship between forgiveness and psychological well-being through structural equation modelling. Sakarya University Journal of Education, 6 (3), 201 - 209, doi: http://dx.doi.org/10.19126/suje.282951

Küçüksille, E. (2014). Çoklu doğrusal regresyon modeli. Ş. Kalaycı (Ed.) SPSS uygulamal çok değişkenli istatistik teknikler içinde, (259-269). Ankara: Asil Yayın Dağıtım.

Lawler Row, K. A. ve Piferi, R. L. (2006). The forgiving personality: predicting a life well lived. Personality and Individual Differences, 41, 1009-1020.

Macaskill, A.,Maltby, J. ve Day, L. (2002). Forgiveness of self and others and emotional empathy. The Journal of Social Psychology, 142 (5), 663-665.

McCullough, M. E.,Pargament, K. I. ve Thoresen, C. E. (2000). The psychology of forgiveness: history, conceptual 1ssues, and overview. M.E. McCullough, K.I. Pargament ve C.E. Thoresen (Eds.), Forgiveness:Theory, research and practice içinde, (1-13). New York: The Guilford Press.

McCullough, M. E., Rachal, K. C., Sandage, S. J., Worthington Jr, E. L., Brown, S. W., ve Hight, T. L. (1998). Interpersonal forgiving in close relationships: II. theoretical elaboration and measurement. Journal of Personality and Social Psychology, 75 (6), 1586-1603.

McCullough, M. E.,Bellah, C. G.,Kilpatrick, S. D. ve Johnson, J. L. (2001). Vengefulness: relationships with forgiveness, rumination, well-being, and the big five. Personality and Social Psychology, 27 (5), 601610. 
Mugrage, M. S. (2014). The relationship between emotional intelligence and forgiveness. (Unpublished Doctoral Dissertation). The Chicago School of Professional Psychology.

North, J. (1987). Wrongdoing and forgiveness. Philosophy. 42, 499-508.

Özer, E. ve Deniz, M. E. (2014). Üniversite öğrencilerinin psikolojik sağlamlık düzeylerinin duygusal zekâ açısından incelenmesi. İlköğretim Online, 13(4), 124-1248, doi: 10.17051/io.2014.74855

Panah, A., Shariff, H. M., ve Koochak-Entezar, R. (2011). The accuracy of emotional intelligence and forgiveness in predicting the degree of satisfaction in marital communications. International Journal of Psychology and Counselling, 3(6), 106-110.

Petrides, K.V., ve Furnham, A. (2000a). On the dimensional structure of emotional intelligence. Personality and Individual Differences, 29(2), 313-320.

Petrides, K. V., ve Furnham, A. (2000b). Gender differences in measured and self-estimated trait emotional intelligence. Sex Roles, 42(5-6), 449-461.

Petrides, K.V. ve Furnham, A. (2001). Trait emotional intelligence: psychometric investigation with reference to established trait taxonomies. European Journal of Personality, 15(6), 425-448.

Petrides, K. V. ve Furnham, A. (2003). Trait emotional intelligence: behavioral validation in two studies of emotion recognition and reactivity to mood induction. European Journal - of Personality, 17(1), 39-57.

Petrides, K. V., Pita, R., ve Kokkinaki, F. (2007). The location of trait emotional intelligence in personality factor space. British Journal of Psychology, 98(2), 273-289.

Roberts, R. (1995). Forgivingness. American Philosophical Quarterly, 32 (4), 289-306.

Ross, S. R.,Kendall, A. C.,Matters, K. G., Rye, M. S. ve Wrobel, T. A. (2004). A personological examination of self - and other-forgiveness in the five factor model. Journal of Personality Assessment, 82, 207-214.

Rye, M. S.,Pargament, K. I.,Ali, M. A.,Beck, G. L.,Dorff, E.N.,Hallisey, C. ve ark. (2000). Religious perspectives on forgiveness. M.E. McCullough, K. I. Pargament ve C.E. Thoresen (Eds.), Forgiveness: Theory, research and practice içinde, (17-41). NY: Guilford Press.

Salovey, P., Bedell, B. T., Detweiler, J. B., ve Mayer, J. D. (1999). Coping intelligently. C.R.

Snyder (Eds.),Coping: The psychology of what works içinde, (141-164). New York: Oxford University Press

Salovey, P., ve Mayer, J. D. (1990). Emotional intelligence. Imagination, Cognition and Personality, 9(3), 185211.

Santrock, J. W. (2011). Yaşam boyu gelişim (Çev. Ed. Galip Yüksel). Ankara: Nobel Yayın Dağıtım. Saracaloğlu, A. S., Saygı, C., Yenice, N. ve Altın, M. (2016). Müzik ve sınıf öğretmeni

adaylarının mükemmeliyetçilik ve duygusal zeka düzeylerinin incelenmesi. Mehmet Akif Ersoy Üniversitesi Eğitim Fakültesi Dergisi, 38, 70-89.

Sarıçam, H. ve Biçer, B. (2015). Affedicilik üzerinde ahlaki değer ve öz-anlayışın açıklayıcı rolü. Gazi Üniversitesi Eğitim Fakültesi Dergisi, 35 (1), 109-122.

Tangney, J. P., Baumeister, R. F., ve Boone, A. L. (2004). High self-control predicts good adjustment, less pathology, better grades, and interpersonal success. Journal of Personality, 72(2), 271-324.

Thompson, L. Y.,Snyder, C. R.,Hoffman, L.,Michael, S. T.,Rasmussen, H. N. ve Billings, L. S. (2005). Dispositional forgiveness of self, others, and situations. Journal of Personality. 73, 313-359.

Van Dyke, C. J., ve Elias, M. J. (2008). How expressions of forgiveness, purpose, and religiosity relate to emotional intelligence and self-concept in urban fifth-grade students. American Journal of Orthopsychiatry, 78(4), 481.

Wade, N. G., ve Meyer, J. E. (2009). Comparison of brief group interventions to promote forgiveness: a pilot outcome study. International Journal of Group Psychotherapy, 59 (2), 199-220. 
Worthington, Jr. E.L. ve Scherer, M. (2004). Forgiveness is an emotion-focused coping strategy that can reduce health risks and promote health resilience: Theory, review, and hypotheses. Psychology and Health, 19(3), 385-405, doi: 10.1080/0887044042000196674.

Worthington, E. L. (1998). An empathy-humility-commitment model of forgiveness appliedwithin family dyads. Journal of Family Therapy, 20, 59-76.

Worthington Jr, E. L., ve Wade, N. G. (1999). The psychology of unforgiveness and forgivenessand implications for clinical practice. Journal of Social and Clinical Psychology, 18(4),385. 
